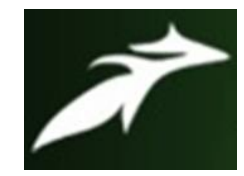

Sentizungla et al, Int. Journal of Advances in Agricultural Science \& Technology,

Vol.8 Issue.10, October-2021, pg. 148-157

ISSN: 2348-1358

Impact Factor: 6.057

NAAS Rating: 3.77

\title{
Agri-Entrepreneural Behaviour of King Chilli Growers Under Dimapur District, Nagaland
}

\author{
Sentizungla ${ }^{1}$; Jahanara ${ }^{2}$; Dipak Kumar Bose ${ }^{3}$ \\ ${ }^{1}$ M.Sc. Ag. (Agricultural Extension and Communication), SHUATS (Prayagraj) \\ ${ }^{2}$ Head of Department, Dept. of Agricultural Extension and Communication, SHUATS (Prayagraj) \\ ${ }^{3}$ Associate Professor, Dept. of Agricultural Extension and Communication, SHUATS (Prayagraj) \\ Author's e-mail: imchensent@ gmail.com \\ DOI: 10.47856/ijaast.2021.v08i10.017
}

\begin{abstract}
The present study was conducted with the objective to find out the socio economic profile, agrientrepreneural behaviour and attitude of king chilli growers in Dimapur district of Nagaland and find out the constraints faced by the respondents and to obtain their suggestions. A total of one hundred twenty farmers were selected from 4 villages using proportionate random sampling procedure. Data was collected by using interview method using pre-structure D interview schedule and analyzed using appropriate statistical tools. The study revealed that majority of the respondents belonged to middle aged group, had medium level of annual income with medium size of land holding. Majority of them had medium year of farming experience and medium level of extension contact. On analyzing the entrepreneural behaviour level, highest number of respondents i.e. $65.83 \%$ were having medium level of entrepreneural behaviour followed by $25 \%$ having high and $9.16 \%$ having low levels. In respect of correlation analysis between entrepreneural behaviour level and socio- economic profile of respondents it shows that annual income, extension contact, mass media exposure and social contact are positively significant. Whereas, age, education, family type, family size, type of house, land holding, and farming experience are non-significant. In respect of the correlation analysis, the annual income, extension contact, mass media exposure and social contact were positively significant at $0.05 \%$ level related to attitude of the people whereas age, education, family type, family size, type of house, land holding, and farming experience were found to be non-significantly related to attitude of the respondents towards king chilli production respectively.
\end{abstract}

Keywords: Agri-entrepreneural behaviour, king chilli growers, Nagaland. 


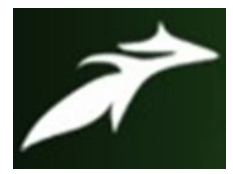

Sentizungla et al, Int. Journal of Advances in Agricultural Science \& Technology, Vol.8 Issue.10, October-2021, pg. 148-157

ISSN: 2348-1358

Impact Factor: 6.057

NAAS Rating: 3.77

\section{Introduction}

In the Northeastern states of India, one of the most popular spices grown is the king chilli (C. chinense). It is grown in the state of Manipur, Assam and Nagaland. King chilli which contains more capsaicin (3-5\%) as compared to any other Indian chilli is a traditional food item of the people of Nagaland and believed to be the original home (Baruah et al., 2014).

Naga King chilli (Capsicum chinense Jacquin) belongs to the genus Capsicum of Solanaceae or nightshade family. Naga King chilli has been considered as the world's hottest chilli and entered in "Guinness book of world records" (measuring 855,000 scoville units), beating the "Mexican red savana habaneros" (5, 77,000 scoville units) (Shetalu, 2010). The State Government of Nagaland also got the patent rights of Naga King chilli and got Geographical indication in the year 2008 from Government of India under Registration and Protection Act, 1999. Demand of Naga King chilli is very high both in domestic and outside market, earlier the State Agriculture Department had tied up marketing linkage with Imperial Tobacco Company (ITC), Spices Limited, Spices Board of India and recently with the International Competence Centre for Organic Agriculture (ICCOA) Bangalore for marketing of dried Naga King chilli outside the state.

King chilli is grown in almost all the districts of the state Nagaland. The area under king chilli cultivation has increased tremendously from 600 ha in 2012-2013 to 1385 ha in 2015-2016 with a total production of 2500 MT and 7739 MT respectively (Statistical Handbook of Nagaland, 2015). It has been reported that production of king Chilli is increased every year in north-eastern India (Meetei et al., 2016).

Traditionally in Nagaland, Naga King chilli are grown in burned bamboo soils while jhumming and also in kitchen gardens with some organic manures such as FYM, poultry droppings, etc. King chilli is highly perishable non-climatic crop can be grown all the types of soil, but a deep loose soil is preferred. Good quality king chilli can be produced under clay loam soil (Borgohain and Devi, 2007). The soil should be rich in organic matter with of $\mathrm{pH}$ 5.5-6.0 The high foothill conditions with high nitrogen available of the region are suitable for the cultivation and production of a extensive range of capsicum crops including king chilli (Rongsennungla $\boldsymbol{e t}$ al., 2012; Sharma, 2014).

Naga King chilli has great potential for value addition as supplement or complementary thereby; as in oleoresin (for treatment of rheumatic disorders), tonic and carminative action, pain balm, prickly heat powders, essential oil (for aroma therapy), capsaicin, capsanthin, its chemical 


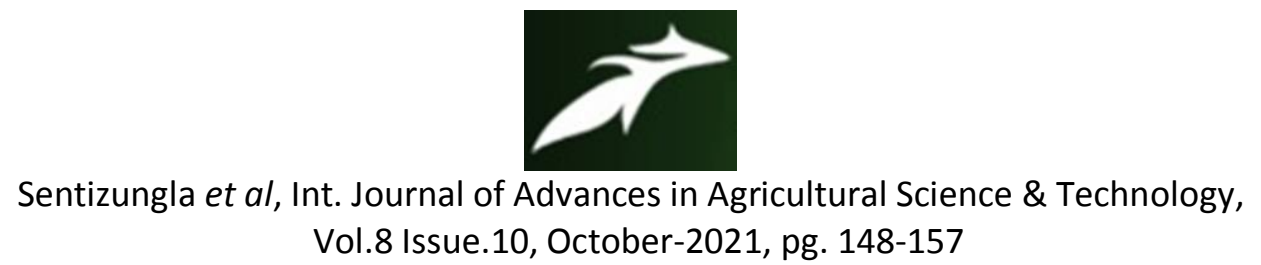

Vol.8 Issue.10, October-2021, pg. 148-157

ISSN: 2348-1358

Impact Factor: 6.057

NAAS Rating: 3.77

constituents are in use in pharmaceutical and food industry as natural colouring etc; which has gained much importance in global market besides using as dried, flakes or ground powder products.

\section{Material and Methods}

The present study was conducted in Niuland block of Dimapur district of Nagaland. A total number of 120 respondents from 4 villages were selected using proportionate random sampling procedure

Data was collected with the help of pre-structured interview schedule. The descriptive survey research design was followed to conduct the present research study.

The socio-economic variables selected for the study were age, education, family type, family size, type of house, annual income, land holding, farm experience, extension contact, mass media exposure and social contact.

The study was undertaken under the following objectives.

i. To assess the socio-economic profile of the respondents

ii. To analyse the agri-entrepreneural behaviour of King chilli growers

\section{Results and Discussion}

Table 1 revealed that majority (68.33\%) of respondents belonged to middle age group of 36-55 years. Most of (43.33\%) of respondents were found to be illiterate. It was found that (70.83\%) of the respondents were having nuclear family. Majority (76.66\%) of the respondents belonged to family size of upto 5 members. Majority $(43.33 \%)$ of the respondents were having semicemented house. It was also found that $(63.33 \%)$ of the respondents were having annual income between 60,000-80,000 rupees. Maximum number of the respondents (59.16\%) had land size between 1 to 2 ha. Majority (63.33\%) of the respondents were having farming experience between 10-20 years.

It was found that (52.5\%) of the respondents were having medium level of extension contact. It was also found that $(61.5 \%)$ of respondents watch television on a daily basis, $(27.5 \%)$ of the 


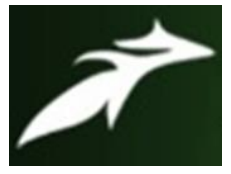

Sentizungla et al, Int. Journal of Advances in Agricultural Science \& Technology,

Vol.8 Issue.10, October-2021, pg. 148-157

ISSN: 2348-1358

Impact Factor: 6.057

NAAS Rating: 3.77

respondents read the newspaper, (21.66\%) sometimes read magazine and only $(5.83 \%)$ of the respondents listen to the radio. Majority of $(88.33 \%)$ of respondents were frequently interacting with friends, (80.83\%) frequently interacted with relatives, (63.33\%) with neighbours and frequently $(25 \%)$ interact with progressive farmers.

Table 1. Socio-economic profile of the respondents

\begin{tabular}{|c|c|c|c|c|}
\hline S.no & $\begin{array}{l}\text { Independent } \\
\text { Variables }\end{array}$ & Category & Frequency & Percentage \\
\hline \multirow[t]{3}{*}{1.} & \multirow[t]{3}{*}{ Age } & Young (20-35) & 18 & 15 \\
\hline & & Middle Age (36-55) & 82 & 68.33 \\
\hline & & Old (Above 55) & 20 & 16.66 \\
\hline \multirow[t]{5}{*}{2.} & \multirow[t]{5}{*}{ Education } & Illiterate & 52 & 43.33 \\
\hline & & \begin{tabular}{|l} 
Primary school \\
\end{tabular} & 30 & 25 \\
\hline & & High School & 23 & 19.16 \\
\hline & & Secondary School & 13 & 10.83 \\
\hline & & Graduation & 2 & 1.66 \\
\hline \multirow[t]{2}{*}{3} & \multirow[t]{2}{*}{ Family type } & Nuclear & 85 & 70.83 \\
\hline & & Joint & 35 & 29.16 \\
\hline \multirow[t]{2}{*}{4} & \multirow[t]{2}{*}{ Family size } & Upto 5 members & 92 & 76.66 \\
\hline & & More than 5 members & 28 & 23.33 \\
\hline
\end{tabular}




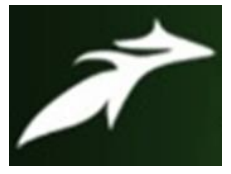

Sentizungla et al, Int. Journal of Advances in Agricultural Science \& Technology,

Vol.8 Issue.10, October-2021, pg. 148-157

ISSN: 2348-1358

Impact Factor: 6.057

NAAS Rating: 3.77

\begin{tabular}{|c|c|c|c|c|c|}
\hline \multirow[t]{3}{*}{5} & \multirow[t]{3}{*}{ Type of house } & \multicolumn{2}{|l|}{ Hut } & 39 & 32.35 \\
\hline & & \multicolumn{2}{|c|}{ Semi-cemented } & 52 & 43.33 \\
\hline & & \multicolumn{2}{|c|}{ Cemented } & 29 & 24.16 \\
\hline \multirow[t]{3}{*}{6} & \multirow[t]{3}{*}{ Annual Income } & \multicolumn{2}{|c|}{ Low $(40,000-56,000)$} & 35 & 29.16 \\
\hline & & \multicolumn{2}{|c|}{ Medium $(57,000-73,000)$} & 58 & 48.33 \\
\hline & & \multicolumn{2}{|c|}{ High $(74,000-90,000)$} & 27 & 22.5 \\
\hline \multirow[t]{3}{*}{7} & \multirow[t]{3}{*}{ Land Holding } & \multicolumn{2}{|c|}{ Less than 1 ha } & 48 & 40 \\
\hline & & \multicolumn{2}{|l|}{$1-2$ ha } & 71 & 59.16 \\
\hline & & \multicolumn{2}{|c|}{ More than 2 ha } & 01 & 0.83 \\
\hline \multirow[t]{3}{*}{8} & \multirow{3}{*}{$\begin{array}{l}\text { Farming } \\
\text { experience }\end{array}$} & \multicolumn{2}{|c|}{ Below 10 years } & 21 & 17.5 \\
\hline & & \multicolumn{2}{|c|}{$10-20$ years } & 76 & 63.33 \\
\hline & & \multicolumn{2}{|c|}{ Above 20 years } & 23 & 19.16 \\
\hline \multirow[t]{3}{*}{9} & Extension contact & \multicolumn{2}{|l|}{ Low } & 42 & 35 \\
\hline & & \multicolumn{2}{|c|}{ Medium } & 63 & 52.5 \\
\hline & & \multicolumn{2}{|l|}{ High } & 15 & 12.5 \\
\hline \multirow[t]{3}{*}{10} & \multirow{3}{*}{$\begin{array}{l}\text { Mass media } \\
\text { exposure }\end{array}$} & \multirow[t]{3}{*}{ Radio } & Daily & 7 & 5.83 \\
\hline & & & Sometimes & 99 & 82.5 \\
\hline & & & Never & 14 & 11.66 \\
\hline
\end{tabular}




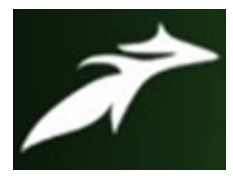

Sentizungla et al, Int. Journal of Advances in Agricultural Science \& Technology,

Vol.8 Issue.10, October-2021, pg. 148-157

ISSN: 2348-1358

Impact Factor: 6.057

NAAS Rating: 3.77

\begin{tabular}{|c|c|c|c|c|c|}
\hline & & Television & Daily & 74 & 61.5 \\
\hline & & & Sometimes & 46 & 38.33 \\
\hline & & & Never & $\mathbf{0}$ & O \\
\hline & & Newspaper & Daily & 33 & 27.5 \\
\hline & & & Sometimes & 87 & 72.5 \\
\hline & & & Never & $\mathbf{0}$ & $\mathbf{0}$ \\
\hline & & Magazines & Daily & $\mathbf{0}$ & $\mathbf{0}$ \\
\hline & & & Sometimes & 26 & 21.66 \\
\hline & & & Never & 94 & 78.33 \\
\hline 11 & Social contact & Neighbour & Always & 76 & \begin{tabular}{|l|l|}
63.33 \\
\end{tabular} \\
\hline & & & Sometimes & 44 & 36.66 \\
\hline & & & Never & $\mathbf{0}$ & $\mathbf{0}$ \\
\hline & & Friends & Always & 106 & 88.33 \\
\hline & & & Sometimes & 14 & 11.66 \\
\hline & & & Never & $\mathbf{0}$ & \begin{tabular}{|ll}
$\mathbf{0}$ \\
\end{tabular} \\
\hline & & Relatives & Always & 97 & 80.83 \\
\hline & & & Sometimes & 23 & 19.16 \\
\hline & & & Never & $\mathbf{0}$ & 0 \\
\hline & & Progressive farmer & Always & 30 & 25 \\
\hline & & & Sometimes & 81 & 67.5 \\
\hline & & & Never & 9 & 7.5 \\
\hline
\end{tabular}

2. Entrepreneural behaviour of the respondents.

The results presented in table 2 revealed that maximum no. of 75 per cent of the respondents have medium level of innovativeness, 85.83 per cent of the respondents had medium level of achievement motivation, 73.33 per cent of the respondents had medium level of risk taking 


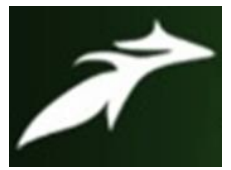

Sentizungla et al, Int. Journal of Advances in Agricultural Science \& Technology,

Vol.8 Issue.10, October-2021, pg. 148-157

ISSN: 2348-1358

Impact Factor: 6.057

NAAS Rating: 3.77

ability, 66.66 per cent of the level of respondents towards entrepreneural intentions and 84.16 per cent of the respondents had medium level of entrepreneural competencies.

Table 2:-Distribution of the respondents according to their entrepreneural behaviour

\begin{tabular}{|c|c|c|c|c|}
\hline S.no & Entrepreneural attributes & Level & Frequency & Percentage \\
\hline \multirow[t]{3}{*}{1.} & \multirow[t]{3}{*}{ Innovativeness } & Low & 30 & 25 \\
\hline & & Medium & 90 & 75 \\
\hline & & High & nil & nil \\
\hline \multirow[t]{3}{*}{2.} & \multirow[t]{3}{*}{ Achievement motivation } & Low & 13 & $\mathbf{1 0 . 8 3}$ \\
\hline & & Medium & 103 & 85.83 \\
\hline & & High & 4 & $\mathbf{3 . 3 3}$ \\
\hline \multirow[t]{3}{*}{3} & \multirow[t]{3}{*}{ Risk taking ability } & Low & 14 & 11.66 \\
\hline & & Medium & 88 & 73.33 \\
\hline & & High & 18 & 15 \\
\hline \multirow[t]{3}{*}{4} & \multirow[t]{3}{*}{ Entrepreneural competencies } & Low & 6 & 5 \\
\hline & & Medium & 80 & 66.66 \\
\hline & & High & 34 & 28.33 \\
\hline \multirow[t]{3}{*}{5} & \multirow[t]{3}{*}{ Entrepreneural intentions } & Low & 19 & 15.83 \\
\hline & & Medium & 101 & 84.16 \\
\hline & & High & nil & nil \\
\hline
\end{tabular}




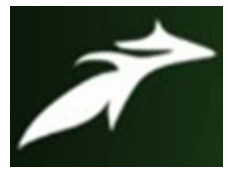

Sentizungla et al, Int. Journal of Advances in Agricultural Science \& Technology,

Vol.8 Issue.10, October-2021, pg. 148-157

ISSN: 2348-1358

Impact Factor: 6.057

NAAS Rating: 3.77

Table 3: Distribution of the respondents based on their level of entrepreneural behaviour

\begin{tabular}{|l|l|l|l|}
\hline S. no & Category & Frequency & Percentage \\
\hline 1 & Low & 11 & 9.16 \\
\hline 2 & Medium & 79 & 65.84 \\
\hline 3 & High & 30 & 25 \\
\hline & Total & 120 & 100 \\
\hline
\end{tabular}

Table 3 revealed that a majority of $65.83 \%$ of the respondents were having medium level of entrepreneural behaviour, followed by $25 \%$ of the respondents having low level of entrepreneural behaviour and $9.16 \%$ of the respondents having high level of entrepreneural behaviour.

Similar findings were reported by Tsubentula Jamir (2020)

3. Association of independent variable with the adoption of recommended practices of off season cucumber cultivation.

Table 4: Association of independent variables with the adoption of recommended practices of off season cucumber cultivation

\begin{tabular}{|l|l|l|}
\hline S.No & Variables & Pearson's correlation coefficient \\
\hline 1 & Age & $0.030 \mathrm{NS}$ \\
\hline 2 & Education & $0.004 \mathrm{NS}$ \\
\hline 3 & Family type & $-0.012 \mathrm{NS}$ \\
\hline 4 & Family size & $0.009 \mathrm{NS}$ \\
\hline 5 & Type of house & $0.154 \mathrm{NS}$ \\
\hline 6 & Annual income & $0.201^{*}$ \\
\hline
\end{tabular}




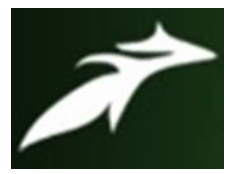

Sentizungla et al, Int. Journal of Advances in Agricultural Science \& Technology, Vol.8 Issue.10, October-2021, pg. 148-157

ISSN: 2348-1358

Impact Factor: 6.057

NAAS Rating: 3.77

\begin{tabular}{|l|l|l|}
\hline 7 & Land holding & 0.031 \\
\hline 8 & Farming experience & $0.017 \mathrm{NS}$ \\
\hline 9 & Extension contact & $0.391^{*}$ \\
\hline 10 & Mass media exposure & $0.429^{*}$ \\
\hline 11 & Social contact & $0.724^{*}$ \\
\hline
\end{tabular}

$*=$ Significant at $\mathrm{p}=0.05 \%, \mathrm{NS}=$ Non Significant

The result of correlation analysis in above table 4 revealed the significance and non-significance of the socio- economic profile of the people and their entrepreneural behaviour.

The finding indicates that annual income, extension contact, mass media exposure, and social contact are significantly associated with the entrepreneural behaviour of the. Whereas age, education, family type, family size, type of house, land holding, and farming experience had non-significant correlation with the entrepreneural behaviour of the responents.

Similar findings were reported by Somvanshi et al., (2016).

\section{Conclusion}

It is therefore concluded from the study that majority of the respondents were middle aged and mostly were illiterate. Most of the respondents had a nuclear family and majority had up to 5 members in the family and most of them lived in semi-cemented house. Majority of the respondents had farming experiences of between 10-20 years. A large number of the respondents had medium level of income. Most of the respondents had medium level of extension contact.

The input on the entrepreneural behaviour showed that the respondents had medium level of entrepreneural behaviour. The major constraints faced by the people were high price fluctuation in market, lack of transportation facilities and lack of godowns/warehouse for proper storage of king chilli. Some suggestions were given by the respondents to overcome some of the constraints such as transport facilities should be made more available and accessable, market information should be made available, proper storage facilities , technical advise and training to be provided, and proper marketing facility should be made available. 


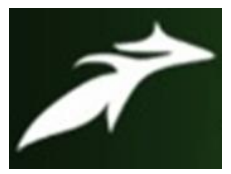

Sentizungla et al, Int. Journal of Advances in Agricultural Science \& Technology, Vol.8 Issue.10, October-2021, pg. 148-157

ISSN: 2348-1358

Impact Factor: 6.057

NAAS Rating: 3.77

\section{References}

[1]. Baruah, S., Zaman, K., Rajbongshi, P. and Das, S. 2014. "A review on recent researches on bhut jolokia and pharmacological activity of capsaicin." International Journal of Pharmaceutical Sciences Review and Research, 24 (2): 89-94

[2]. Bhagowati, R. R., and Changkija, S. 2009. "Genetic variability and traditional practices in naga king chilli landraces of Nagaland." Asian Agri-History, 13 (3) : 171-80.

[3]. Indira, P.; Rajalekshmi, V. S. and Peter, K. V. (2007). “All about Capsicum species." Indian Spices. 34: 10-20.

[4]. Jamir, T. 2020. "Entrepreneurial behavioural pattern of king chilli farmers in Peren district of Nagaland.” M.Sc. (Ag) Thesis, Nagaland University, School of Agricultural Sciences and Rural Development, Medziphema campus, India.

[5]. Jha, K. K., 2019 "Adoption of recommended oroduction technology by chilli growers in Tripura”. Indian Journal of Extension, 55 (3) : 117-122.

[6]. Sarwa, K. K., Kira, J., Sahu, J., Rudrapal, M. and Debnath, M. 2012. "A short review on capsicum chinense." Journal of Herbal Medicine and Toxicology, 6 (2) : 7-10.

[7]. Sharma, A. 2014. "Sustainable economic analysis and extent of satisfaction level of king chilli growers in Nagaland." Agriculture for Sustainable Development, 2 (1) : 71-4.

[8]. Sharma, A. 2016. "Sustainable economic analysis and constraints faced by the naga king chilli growers in Nagaland." Indian Journal of Agricultural Research, 50 (3) : 220-5.

[9]. Shetalu, Vadeo. 2010. "Production and marketing of Naga King chilli cultivation in Dimapur district of Nagaland.” M.Sc. (Ag) Thesis, Nagaland University, School of Agricultural Sciences and Rural Development, Medziphema campus, India.

[10].Somvanshi, R. M., Deshmukh, A. N., Mokhale, S. U. and Godase, S. K. 2016. "Entrepreneurial behaviour of vegetable growers." Agriculture Update, 11 (3) : 239-241. 